\title{
Systematic Review of the Research on Motor Fitness of 1st- Year Students Attending Polish Institutions of Higher Education
}

\author{
Robert Podstawski \\ Department of Physical Education and Sport \\ University of Warmia \& Mazury in Olsztyn \\ Prawocheńskiego 7, 10-720 Olsztyn, Poland \\ Tel. (+4889) 52333 08), mobile: +48601652527 \\ E-mail: podstawskirobert@gmail.com
}

Received: 28-07- 2013

doi:10.7575/aiac.ijkss.v.1n.3p.25
Accepted: 19-09- 2013

Published: 15-10- 2013

URL: http://dx.doi.org/10.7575/aiac.ijkss.v.2n.1p.25

\begin{abstract}
Aim of the study. To establish: 1) the amount of research on general motor fitness of $1^{\text {st }}$-year students, conducted at selected Polish institutions of higher education between 1953-2010;2) the number and kind of motor tests applied in this kind of research as well as the frequency of these tests during the period under study. Material and methods: The material for this research was composed of the publications on motor fitness of the first-year students taking part in specific motor trials applied at Polish tertiary institutions between 1953 - 2010. A diagnostic poll method was used in the research. Results: Fifty-four original research cases conducted in the period under study were observed. Within this period the trials such as: "100m run", "jump from the run-up", "grenade throw" and " shot put" were more popular during the earlier years, while the trials such us: "zig-zag run", "standing long jump", and "medicine ball throw" were characteristic of more recent studies. Some of the most popular motor trials were: "standing long jump" 38 cases, "medicine ball throw" - 30 cases, "zig-zag run" -28 cases, "shuttle runs" -9 cases, "short distance runs" 12 cases, "downward bend from standing position" - 10 cases, and "vertical jump" -8 cases.
\end{abstract}

Conclusions: 1. Little research concerning the level of physical fitness of first-year students attending Polish tertiary institutions was conducted in the years 1953-2010; 2. The amount of motor fitness research carried out during this period fails to provide constant systematic assessment of the state of the students' physical condition, which is a result of too large dispersions in time and territory where the measurements were taken; 3 . In the motor fitness tests conducted with $1^{\text {st }}$-year students the determining variable was mainly gender, and only few research cases were found in which general motor fitness was analyzed according to environmental factors and anthropometric parameters; 4. The popularity of some trials as well as the frequency of their applications fluctuated differently over time.

Keywords: first-year students, motor fitness tests, the years 1953-2010, Poland

\section{Introduction}

Motor fitness is one of the main indicators of human health and development, which is why it takes pride of place among the sciences of physical culture as the subject of numerous works. Despite the changes of views on the definition and assessment of motor fitness, testing is still a very important link in the control of human motor development (Osiński, 1998). Therefore, each physical training should be appropriately monitored. This principle applies in the case of both sport and health training as well as to compulsory classes of PE, for instance, the lessons conducted with university students. There are numerous applications for properly conducted motor fitness tests, namely:

$>$ within a relatively short period of time a vast amount of new information on the students' lifestyle is provided, on the basis of which adequate, and if necessary, corrective measures can be undertaken;

$>$ with reference to an individual student, the measurement of his/her level of motor fitness may enhance a positive approach towards his/her body, enabling him/her to become conscious of his/her own level of motor development and, in consequence, better motor fitness;

$>$ motor tests can reveal individual or group health deficiencies (as a result of a single measurement or observations made within a course of time in the form of cross-sectional or longitudinal studies), which can serve the basis for estimating and advocating possible remedial measures; 
as regards practicing sports, motor tests can show weaknesses in general or specific aspects of motor fitness, and consequently help prevent sports injuries; or conversely, they can reveal hidden predispositions and abilities as well as motor skills which an individual would like to improve;

$>$ modified forms of motor tests are used to examine handicapped children and youth (including mentally retarded) and help adjust physical activities to their needs (e.g., Pilicz, 1997, Szopa \& Grabowski, 1991)

Continuous expansion of so-called 'diseases of civilization' as well as a systematic decrease in the level of physical activity raises the importance of the research in this area, which in some cases appears to be the most accurate method of surveying the health prospects of specific populations (Drabik, 1989; Eriksen, 2001; Marsch, 1993). The effect of physical activity on the health of children, adolescents and adults has been frequently portrayed in foreign (Corbin, 2002; Crespo, Ainsworth, Keteyian, Health, \& Smit, 1999; Kemper, 1995; Pangrazi, Corbin, \& Welk, 1996) and Polish literature (Astrand, 2000; Drabik, 2006; Mynarski, Garbaciak, Stokłosa, \& Grządziel, 2007, Osiński, 2003; Szopa, 1999).

Researchers are not unanimous in defining the concept of motor fitness, which is often identified with the term physical fitness(Pilicz, 1997; Raczek, 2010). Various approaches which reflect the scientists' conflicting views on the subject have frequently aroused controversy. The overview of the Polish standpoints and opinions was presented int.al. in the work by Drabik (1997), Mynarski (2000), Osiński (2003), Pilicz (1996), Przewęda \& Trześniowski (1996), Raczek (1991), and Szopa (1998).

The studies of human motor fitness concentrate on subsequent stages of a person's ontogenetic development as well as of particular social groups worldwide (Caspersen, Powell, \& Christenson, 1985; Dishman, Sallis, Orenstein, 1985; Labbe \& Welsh, 1993; Howley \& Franks, 1997; Przewęda \& Dobosz, 2007; Skinner \& Oja, 1994; Tomkinson, 2007; Tomkinson \& Olds, 2007). This work has focused on the research investigating the level of motor fitness of Polish students during their first year of study. While describing and explaining the relevant issues, the basic concepts used in the field of motor fitness have been adopted.

In this article the term motor fitness should be interpreted in accordance with Raczek's view as:"...a degree of manifestation of the level and structure of an individual's determinants (potential) to perform physical activities. Therefore, not only is [motor fitness] described by the level of motor abilities (traditional interpretation), but also by motor skills and a kind of interdependences and relationships between them. Motor fitness is a concept of a more general scope than physical fitness. Motor fitness can manifest itself only by activation of mental processes and an individual's behavior. Consequently, it is determined by the nature of decision-making processes."(Raczek, 2010, p. 62).

Furthermore, according to Szopa "the definition of motor abilities combines the elements of the potential side as well as the effective, integrated by the common ground of biology and movement. As a result, the classification is determined not only by predispositions and motor skills essential for the given ability, but also the parameters that are typical of the different types of movements."(Szopa, 1998, p. 79-80).

Additionally, referring to Przewęda's concept (1996), the author in question states that "motor fitness" should be considered in three related categories:

$>$ the level of motor abilities which enables a person to perform a motor task (a person "can do"),

$>$ a range of motor skills which determine the ability to perform motor tasks (a person "knows how to do"),

$>$ motivation and attitude which condition the achievement of the pursued goal (a person "wants to do").

In this perspective, motor fitness becomes an individual's personal property rather than the characteristic of his/her motor activity. It refers to the person as a biosocial unity, not only to his/her physical, or even solely, to his/her motor apparatus, as motor fitness is an important (...) aspect of every action, every human activity." (Raczek, 2010, p. 63).

In addition, the term research in the title of this work should be interpreted as a set of publications on the subject of motor fitness of the first-year students conducted at Polish institutions of higher education between $1054-2010$, whereas the term test denotes " a standardized and normalized trial which makes it possible to infer conclusions about the attributes of motor fitness not available for direct measurements, which is the basis for the comparison of individuals and groups in order to determine individual differences etc..”(Raczek, 2010, p. 286). It was also assumed after Pilicz, that motor tasks (movement tests) are prevalent methods of measurements while testing motor fitness, and their type and number vary in each test (Pilicz, 1997, p. 17). Therefore, a test can be a sample or a set of tests often referred to as a test battery (Przewęda \& Trześniowski, 1996, p. 22). However, not every motor trial can be a test.

The aim of this study was to present a number of publications on the subject of research on motor fitness of the firstyear students at selected Polish tertiary institutions (PTI) in the years $1953-2010$. The objective formulated accordingly was achieved by means of answering the following questions:

1. What is the number of publications on the subject of motor fitness of first-year male and female students attending selected PTI in the years 1953-2010?

2. What type of Polish institutions of higher education participated in the motor fitness tests the most and least frequently? 
3. Whose research involved the highest number of students?

4. Which motor tests were the most popular in the period under study?

5. What was the frequency of the specific motor tests throughout the period under investigation?

\section{Material and Methods}

\subsection{Ethical consideration}

The research was carried out with prior approval of the Ethical Committee of UWM.

\subsection{Study material}

The material consisted of the works published in the period of 1953-2010 in the field of research on students' motor fitness. The analysis related to the number and type of the motor tests as well as the number of the first-year students participating in the study.

\subsection{Data collection tool}

A diagnostic survey method was used in the study along with a thorough analysis of the documents in the form of published articles. A systematic review of the research on the $1^{\text {st }}$ year students' motor fitness was based on the following principles:

the present research focuses only on the Polish studies published in scientific journals, monographs, and chapters in monographs,

the students enrolled at the Faculties of Physical Education and Sports Sciences (mainly in Polish Academies of Physical Education) as well as the students of military and police schools of higher education, were excluded from our research on the grounds of the specificity of their curriculum, and the principles of selection and screening required from the candidates to be enrolled for these courses,

The publications were arranged chronologically according to the year of the conducted research.

\section{Results}

The data presented in table 1 shows the number of publications on the subject of motor fitness of first-year students. Additionally, it provides information on the number of university students participating in the study as well as the respondents' gender.

Table 1 . The number of publications and the number of $1^{\text {st }}$ year students' participating in the research on motor fitness

\begin{tabular}{|c|c|c|c|c|}
\hline \multirow{2}{*}{ No. } & \multicolumn{3}{|c|}{ Number of students participating in research } & \multirow{2}{*}{ Number of author's publications } \\
\hline & Women & Men & Total & \\
\hline 1 & 335 & 2164 & 2499 & 54 (Pilicz, 1958) \\
\hline 2 & 4278 & 7629 & 11907 & 16 (Demel \& Sikora, 1959) \\
\hline 3 & * & 6395 & 6395 & 55 (Pilicz, 1963) \\
\hline 4 & 500 & 300 & 800 & 25 (Kobielski \& Konior, 1958) \\
\hline 5 & $*$ & 382 & 382 & 25 (Grus, 1980) \\
\hline 6 & * & 344 & 344 & 76 (Silski, 1966) \\
\hline 7 & 800 & 800 & 1600 & 15 (Demel \& Pilicz, 1966) \\
\hline 8 & 459 & 467 & 926 & 56 (Pilicz, 1973) \\
\hline 9 & 459 & * & 459 & 62 (Pilicz, 1973) \\
\hline 10 & $*$ & 214 & 214 & 24 (Grus, 1977b) \\
\hline 11 & 467 & * & 467 & 61 (Pilicz, 1971) \\
\hline 12 & $*$ & 1060 & 1060 & 29 (Jaskólski, Niemiec, \& Śliwa) 1970 \\
\hline 13 & 77 & 104 & 181 & 30 (Jaskólski, Niemiec, \& Śliwa) 1972 \\
\hline 14 & * & 139 & 139 & 92 (Wierbicki, 1975) \\
\hline 15 & $*$ & 121 & 121 & 23(Grus, 1977a) \\
\hline 16 & 467 & $*$ & 467 & 46 (Mroczyński, 1974) \\
\hline 17 & 3053 & * & 3053 & 5 (Burdziński, 1977a) \\
\hline 18 & 210 & 682 & 892 & 4(Brodecki, 1977) \\
\hline 19 & $*$ & 600 & 600 & 42 (Malanowicz, 1977) \\
\hline 10 & * & 3616 & 3616 & 77(Silski, 1981) \\
\hline 21 & * & 130 & 130 & 47 (Mroczyński, 1979) \\
\hline 22 & 370 & 66 & 436 & 32 (Jopkiewicz \& Kosztołowicz, 1978) \\
\hline 23 & * & 470 & 470 & 6 (Burdziński, 1977b) \\
\hline 24 & 1314 & * & 1314 & 86(Szymański, 1998) \\
\hline 25 & $*$ & 165 & 165 & 14 (Deckert \& Kobielski, 1977) \\
\hline 26 & * & 344 & 344 & 45 (Mroczkowski, 1976) \\
\hline 27 & 244 & * & 244 & 8 (Chlebicka, 1983) \\
\hline 28 & 37 & * & 37 & 44 (Mroczkowska, 1979) \\
\hline
\end{tabular}




\begin{tabular}{|c|c|c|c|c|}
\hline 29 & $*$ & 470 & 470 & 12 (Czapla \& Malanowicz, 1979) \\
\hline 30 & 3596 & 3584 & 7180 & 57 (Pilicz, 1982) \\
\hline 31 & 279 & 47 & 326 & 13 (Czaplicki, 1997) \\
\hline 32 & 861 & 602 & 1463 & 26 (Grzesiak, 1998) \\
\hline 33 & 307 & * & 307 & 75 (Rodziewicz-Gruhn et al., 1997) \\
\hline 34 & 686 & 316 & 1002 & 21 (Drabik \& Orzechowski, 1999) \\
\hline 35 & 185 & 173 & 358 & 35 (Kuchnio \& Foriasz, 2006) \\
\hline 36 & 379 & 567 & 946 & 3 (Bratkowska-Gołaszewska, 2000) \\
\hline 37 & 1473 & 1800 & 3273 & 39 (Lisicki, 2002) \\
\hline 38 & 178 & * & 178 & 87 (Tatarczuk \& Asienkiewicz, 2008) \\
\hline 39 & 1192 & 362 & 1554 & 31 (Jopkiewicz, Przychodni \& Markowska, 2004) \\
\hline 40 & $\Theta$ & $\Theta$ & 1638 (C) & 91 (Umiastowska, 2007) \\
\hline 41 & 1925 & 1642 & 3567 & 65 (Podstawski, 2010) \\
\hline 42 & 132 & 84 & 216 & 88 (Tatrcz \& Wandycz, 2006) \\
\hline 43 & 182 & * & 182 & 41 (Lisicki \& Drygas, 2005) \\
\hline 44 & 219 & * & 219 & 67 (Podstawski, Choszcz, \& Wysocka-Welanc, 2006) \\
\hline 45 & $*$ & 119 & 119 & 9 (Choszcz, Podstawski, \& Wysocka-Welanc, 2009) \\
\hline Total & 24664 & 35958 & 62240 & 45 \\
\hline
\end{tabular}

Overall 45 original publications were found on the subject of first-year students' motor fitness. Of all the publications, 19 referred to both females and males, 15 focused exclusively on men, and 11 on women. Taking into account all the studies, 29 of them related to women whereas 33 to men. The review of the literature in this field indicates a considerable number of publications which are compilations of several studies contained also within this work. A total number of all the university students participating in the study was 60,622, comprising 24664 women and 35958 men. The research that covered the largest number of first-year students consisted of the motor fitness tests conducted by Demel and Sikora (1959) in 1954 with the group of 11,907 women and men attending schools of higher education such as: universities, medical schools and technical colleges. The second largest group of participants (comprising 7180 men and women) fell within the scope of the research by Pilicz (1982) in 1979, which was conducted at an impressive number of 38 tertiary institutions, including: 5 universities, 10 polytechnics, 6 medical academies, 3 schools of economics, 4 schools of agriculture, 6 pedagogic colleges and 4 arts schools. The third highest number of participants were involved in the study by Pilicz (1963), carried out with the students of Warsaw Polytechnic in the years 1954-1959, the scope of which covered 6,395 men. The results of the above research were unique and never repeated on such a big scale. It should be noted, however, that only research which is conducted in several tertiary institutions simultaneously offers a possibility to present a true picture of the students' motor fitness in a given country. An attempt to show the level of physical fitness of the $1^{\text {st }}$-year students attending selected schools of higher education in Tricity (the urban sprawl of Gdańsk, Gdynia and Sopot) was made by Lisicki (2002). Those studies, however, were not as broad in scope but rather limited to a particular region of the country. The least numerous group of students (37 women) participated in the research conducted at the Gdynia Maritime School in the academic year 1977/78. There is no denying that some types of schools are gender specific with a prevailing number of one sex (Tab. 1). Table 2 shows the overview of the publications concerning the frequency of the conducted studies on motor fitness between 1953-2010.

Table 2. Frequency of conducted research on $1^{\text {st }}$ year students' motor fitness at different types of Polish tertiary institutions in the years 1953-2010

\begin{tabular}{|c|c|c|c|c|c|c|}
\hline \multirow{2}{*}{$\begin{array}{l}\text { Types of tertiary } \\
\text { institutions in which } \\
\text { research was conducted }\end{array}$} & \multicolumn{6}{|c|}{ Numbers of publications in which given schools are listed with consideration of sex } \\
\hline & Total & $\mathrm{N}$ & Women & $\mathrm{N}$ & Men & $\mathrm{N}$ \\
\hline Universities & $\begin{array}{c}5,6,9,15,16,39,57,65 \\
67,87,88,91\end{array}$ & 12 & $\begin{array}{c}5,15,16,39,57,65 \\
67,87,88,91\end{array}$ & 10 & $\begin{array}{c}6,9,15,16,39,57,65 \\
88,91\end{array}$ & 9 \\
\hline Technical colleges & $\begin{array}{c}3,4,8,12,15,16,26,29 \\
30,39,42,47,54,55,56 \\
57,61,62,76,77,91\end{array}$ & 21 & $\begin{array}{c}3,4,8,12,15,16 \\
26,30,39,54,56 \\
57,61,62,91\end{array}$ & 15 & $\begin{array}{c}3,4,12,15,16,26,29 \\
30,39,42,47,54,55 \\
57,76,77,91\end{array}$ & 17 \\
\hline Pedagogical colleges & $13,26,31,32,35,57,75$ & 8 & $\begin{array}{c}13,26,31,32,35,57 \\
75,86\end{array}$ & 8 & $13,26,31,32,35,57$ & 6 \\
\hline Medicine Academies & $\begin{array}{c}14,16,21,23,24,34,39 \\
41,57,91\end{array}$ & 10 & $\begin{array}{l}14,16,21,23,24 \\
34,39,41,57,91\end{array}$ & 10 & $\begin{array}{c}14,16,21,23,24,34 \\
39,57,91\end{array}$ & 9 \\
\hline Economic colleges & 15,57 & 2 & 15,57 & 2 & 15,57 & 2 \\
\hline Art. colleges & $23,24,25,57$ & 4 & $23,24,57$ & 3 & $23,24,25,57$ & 4 \\
\hline Naval Academies & $39,44,45,91$ & 4 & $39,44,91$ & 3 & $39,45,91$ & 3 \\
\hline Agriculture colleges & $3,15,92,46,47,57,91$ & 7 & $3,15,46,57,91$ & 5 & $3,15,92,47,57,91$ & 6 \\
\hline Total & 68 & & 54 & & 56 & \\
\hline
\end{tabular}

Note: $\mathrm{N}$ - number of cases 
Table 2 gives the number of studies on first-year students' motor fitness at Polish schools of higher education. There were 68 studies including 54 original research cases focusing exclusively on women and 56 on men. The number of research cases relating to particular schools of higher education exceeds the number of publications devoted to the subject due to the fact that some of the studies included several or even dozens of tertiary institutions in Poland. On the basis of the collected data it can be stated that on average in every type of school about 8 cases of studies in the field of motor fitness were conducted (the same number of approx. 7 cases with reference to both male and female study groups). Most studies of first year students' motor fitness were carried out in the universities and colleges of technology (21 cases), and in the second place in this regard were universities (12 cases), while medical schools were the third (10 cases). A considerably fewer measurements of first-year students' motor fitness were conducted in other types of institutions of higher education, with the smallest number in the higher schools of economics ( 2 cases).

A similar distribution of the frequency of the studies was observed in relation to the gender of participants. The highest number of cases referred to the male students (17 cases) and female students (15 cases) attending technical schools of higher education. In the case of universities and medical schools, 10 research cases on motor fitness of the men and 9 cases of the women were found in each of the place. Taking into account almost a 60-year period of the observations, it can be assumed that on average less than one research case $(0.88)$ occurred each year, whereas taking into consideration the number of Polish schools of higher education, this number will be reduced accordingly even more (Tab. 2).

The data presented in table 3 indicates the frequency of motor trials used in the studies on first-year students' motor fitness.

Table 3. Frequency of conducting individual motor tests in research of $1^{\text {st }}$ year college students in Poland between $1953-2010$

\begin{tabular}{|c|c|c|c|c|c|c|}
\hline \multirow{2}{*}{ Types of motor tests } & \multicolumn{6}{|c|}{ Numbers of publications in which given trials are listed with consideration of sex } \\
\hline & Total & $\mathrm{N}$ & Women & $\mathrm{N}$ & Men & $\mathrm{N}$ \\
\hline Long distance runs $^{\text {a) }}$ & $8,16,77$ & 3 & 8,16 & 2 & 16,77 & 2 \\
\hline $300 \mathrm{~m}$ distance run & 29,30 & 2 & 30 & 1 & 29,30 & 2 \\
\hline Short distance runs ${ }^{\mathrm{b})}$ & $\begin{array}{c}8,13,15,16,25,29,30,34,54 \\
55,76,77\end{array}$ & 12 & $8,13,15,16,25,30,54$ & 7 & $\begin{array}{c}13,15,16,25,29,30,34 \\
54,55,76,77\end{array}$ & 11 \\
\hline Shuttle runs $^{c)}$ & $3,8,12,35,39,41,65,77,91$ & 9 & $3,8,12,35,39,41,65,91$ & 8 & $3,12,35,39,65,77,91$ & 7 \\
\hline Zig- zag run & $\begin{array}{c}4,5,6,12,13,14,23,24,26,29 \\
30,32,42,44,45,46,47,56,57 \\
61,62,75,86,92,87,88,91\end{array}$ & 27 & $\begin{array}{c}4,5,12,13,14,23,24,26,30 \\
32,42,44,46,56,57,61,62 \\
75,86,87,88,91\end{array}$ & 22 & $\begin{array}{c}4,6,12,13,14,23,24 \\
26,29,30,32,45,47,57 \\
88,92,91\end{array}$ & 17 \\
\hline $\begin{array}{l}\text { Skipping with clapping } \\
\text { of hands }-8 \mathrm{~s}\end{array}$ & 65 & 1 & 65 & 1 & 65 & 1 \\
\hline Cooper test (12 min) & 13,21 & 2 & 13,21 & 2 & 13,21 & 2 \\
\hline Marches d) $^{\text {d) }}$ & 16 & 1 & 16 & 1 & 16 & 1 \\
\hline Standing long jump ${ }^{\text {e) }}$ & $\begin{array}{c}3,4,5,6,8,13,14,15,16,23 \\
24,25,26,29,30,32,34,35,39 \\
41,42,46,47,54,55,56,57,61 \\
62,65,75,76,77,86,87,88,91\end{array}$ & 37 & $\begin{array}{c}3,4,5,8,13,14,15,16,23 \\
24,26,30,32,34,35,39,41 \\
42,46,54,56,57,61,62,65 \\
75,86,87,88,91\end{array}$ & 30 & $\begin{array}{c}3,4,6,13,14,15,16,23 \\
24,25,26,29,30,32,34 \\
35,39,47,54,55,57,65 \\
76,77,88,91\end{array}$ & 26 \\
\hline Vertical jump (Sargent's) & $4,5,6,12,26,44,45,47,76$ & 9 & $4,5,12,26,44$ & 5 & $4,6,12,26,45,47,76$ & 7 \\
\hline Grenade throw & $15,16,34$ & 3 & $15,16,34$ & 3 & $15,16,34$ & 3 \\
\hline Shot put ${ }^{f)}$ & $25,54,55,76$ & 4 & 54 & 1 & $25,54,55,76$ & 4 \\
\hline Obstacle course & 16 & 1 & 16 & 1 & 16 & 1 \\
\hline Medicine ball throw ${ }^{\mathrm{g})}$ & $\begin{array}{c}4,6,12,13,14,23,24,26,29 \\
30,32,35,39,41,42,44,46,47 \\
56,57,61,62,65,75,86,87,88 \\
91\end{array}$ & 28 & $\begin{array}{c}4,12,13,14,23,24,26,30 \\
32,35,39,41,42,44,46,56 \\
57,61,62,65,75,86,87,88 \\
91\end{array}$ & 25 & $\begin{array}{c}4,6,12,13,14,23,24 \\
26,29,30,32,35,39,47 \\
57,65,88,91\end{array}$ & 18 \\
\hline $\begin{array}{l}\text { Downward bend from } \\
\text { standing position }\end{array}$ & $\begin{array}{c}4,5,6,8,26,35,39,41,65,77 \\
87\end{array}$ & 11 & $4,5,8,26,35,39,41,65,87$ & 9 & $4,6,26,35,39,65,77$ & 7 \\
\hline $\begin{array}{c}\text { Flexibility test } \\
\text { (Szafarkiewicz's) }\end{array}$ & 47 & 1 & Lack & 0 & 47 & 1 \\
\hline Sit and reach & $3,65,91$ & 3 & $3,65,91$ & 3 & $3,65,91$ & 3 \\
\hline $\begin{array}{c}\text { Squats with backward } \\
\text { legs extentions }{ }^{\mathrm{h}}\end{array}$ & $12,26,47,65,75,87,88$ & 7 & $12,26,65,75,87,88$ & 6 & $12,26,47,65,88$ & 5 \\
\hline Hand dynamometer trial & $3,35,57,91$ & 4 & $3,35,57,91$ & 4 & $3,35,57,91$ & 4 \\
\hline Balance trial (Flamini's) & 3 & 1 & 3 & 1 & 3 & 1 \\
\hline Tapping & 3 & 1 & 3 & 1 & 3 & 1 \\
\hline Sit-ups-30s & $3,8,65,77,91$ & 5 & $3,8,65,91$ & 4 & $3,65,77,91$ & 4 \\
\hline Flexed-arm hang & $3,8,65$ & 3 & $3,8,65$ & 3 & 3,65 & 2 \\
\hline Push-ups & 29,30 & 2 & 30 & 1 & 29,30 & 2 \\
\hline Pull-ups on a bar & $39,65,76,77$ & 4 & 39,65 & 2 & $39,65,76,77$ & 4 \\
\hline Rowing ergometer-500m & $9,65,67$ & 3 & 65,67 & 2 & 9,65 & 2 \\
\hline ETKF $\mathrm{VO}_{2 \max }$ & 31 & 1 & 31 & 1 & 31 & 1 \\
\hline
\end{tabular}

The findings of the research revealed that while measuring first-year students' motor fitness 27 motor tests were applied, some of which had several variations. The tests which vary in respect of the type are the following: short and 
long distance runs, shuttle runs, marches, shot puts, medicine ball throws, squats with backward legs extensions (often called the Burpee tests).

Out of all the tests, the most popular were: the standing long jump - 37 cases, (women- 30, and men - 26), the medicine ball throw -28 cases (women - 30, and men - 26), and the zig-zag run -27 cases (women - 22, and men 17). Within the group of less popular tests were: short distance runs -12 cases (women -7 , and men - 11), and the downward bend from standing position - 11 cases (women - 9, and men - 7). Other motor tests were performed less than 10 times between 1954-2010. The group of tests carried out only on one occasion included 10 trials: the skipping with clapping of hands - 8(in both sexes), the marches (in both sexes), the obstacle course (in both sexes), the balance trial (Flamini's) (in both sexes), the tapping (in both sexes), the ETKF $\mathrm{VO}_{2 \max }$ (in both sexes), the push-ups (in men), the $300 \mathrm{~m}$ run (in women), the shot put (in women), the Szafarkiewicz's flexibility test (in men) (Tab. 3).

Tables 4a, 4b and4c, present the evaluation and the frequency of particular motor tests between 1953-2010.

Table 4a. Types of motor tests applied in research on $1^{\text {st }}$ year students attending Polish tertiary institutions between 1953-1976

\begin{tabular}{|c|c|c|c|c|c|c|c|c|c|c|c|c|c|c|}
\hline \multirow[b]{2}{*}{ Types of motor tests } & \multicolumn{14}{|c|}{ Years of applying specific motor tests and numbers of individual authors' publications } \\
\hline & $\stackrel{m}{a}$ & $\stackrel{+}{2}$ & 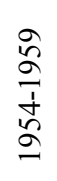 & 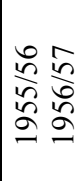 & 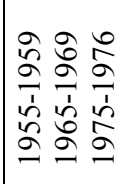 & 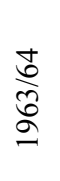 & ఫั & $\begin{array}{l}2 \\
\stackrel{2}{0} \\
2 \\
02 \\
2\end{array}$ & 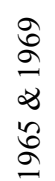 & $\begin{array}{l}\frac{1}{5} \\
\frac{1}{1} \\
\vdots \\
\vdots \\
\vdots\end{array}$ & 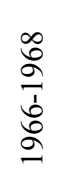 & $\begin{array}{l}2 \\
\infty \\
\infty \\
0\end{array}$ & 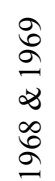 & ڤे \\
\hline Long distance runs ${ }^{\text {a) }}$ & & 16 & & & & & & & & & & & & \\
\hline $300 \mathrm{~m}$ distance run & & & & & & & & & & & & 29 & 30 & \\
\hline Short distance runs ${ }^{\text {b) }}$ & 54 & 16 & 55 & 34 & 25 & 76 & 15 & & & & & 29 & 30 & \\
\hline \multicolumn{15}{|l|}{ Shuttle runs ${ }^{\mathrm{c})}$} \\
\hline Zig- zag run & & & & & & & & 56 & 62 & 24 & 61 & 29 & 30 & 92 \\
\hline \multicolumn{15}{|l|}{$\begin{array}{l}\text { Skipping with clapping of } \\
\text { hands }-8 \mathrm{~s}\end{array}$} \\
\hline \multicolumn{15}{|l|}{ Cooper test $(12 \mathrm{~min})$} \\
\hline Marches d) & & 16 & & & & & & & & & & & & \\
\hline Standing long jump ${ }^{\mathrm{e})}$ & 54 & 16 & 55 & 34 & 25 & 76 & 15 & 56 & 62 & 24 & 61 & 29 & 30 & \\
\hline Vertical jump (Sargent's) & & & & & & 76 & & & & & & & & \\
\hline Grenade throw & & 16 & & 34 & & & 15 & & & & & & & \\
\hline Shot put ${ }^{f)}$ & 54 & & 55 & & 24 & 76 & & & & & & & & \\
\hline Obstacle course & & 16 & & & & & & & & & & & & \\
\hline Medicine ball throw ${ }^{\mathrm{g})}$ & & & & & & & & 56 & 62 & 24 & 61 & 29 & 30 & \\
\hline \multicolumn{15}{|l|}{$\begin{array}{l}\text { Downward bend from } \\
\text { standing position }\end{array}$} \\
\hline \multicolumn{15}{|l|}{$\begin{array}{c}\text { Flexibility test } \\
\text { (Szafarkiewicz's) }\end{array}$} \\
\hline \multicolumn{15}{|l|}{ Sit and reach } \\
\hline \multicolumn{15}{|l|}{$\begin{array}{c}\text { Squats with backward legs } \\
\text { extentions }{ }^{h}\end{array}$} \\
\hline \multicolumn{15}{|l|}{ Hand dynamometer trial } \\
\hline \multicolumn{15}{|l|}{ Balance trial (Flamini's) } \\
\hline \multicolumn{15}{|l|}{ Tapping } \\
\hline \multicolumn{15}{|l|}{ Sit-ups-30s } \\
\hline \multicolumn{15}{|l|}{ Flexed-arm hang } \\
\hline Push-ups & & & & & & & & & & & & 29 & 30 & \\
\hline Pull-ups on a bar & & & & & & 76 & & & & & & & & \\
\hline Rowing ergometer- $500 \mathrm{~m}$ & & & & & & & & & & & & & & \\
\hline ETKF VO $V_{2 \max }$ & & & & & & & & & & & & & & \\
\hline
\end{tabular}

Note: $\mathrm{a}-$ most frequent 1000 , and $500 \mathrm{~m} ; \mathrm{b}-$ most frequent $100 \mathrm{~m}$, as well as $60 \mathrm{~m}$ or $50 \mathrm{~m}$; $\mathrm{c}-4 \times 10 \mathrm{~m}$ or $4 \times 18 \mathrm{~m}$ or $4 \times 5 \mathrm{~m} ; \mathrm{d}-10 \mathrm{~km}$ and $5 \mathrm{~km}$; e - originally mainly from a running start, later from a standstill ; $\mathrm{f}-7,25 \mathrm{~kg}$ shot put (men) and 0,5kg (women); g- backward or forward, $3 \mathrm{~kg}$ ball (men) and $2 \mathrm{~kg}$ ball(men and women); $\mathrm{h}-\mathrm{in}$ duration 30 s or 60 s.

Taking into account the years of the conducted research, we can assume that the trials such as: short distance runs, marches, the standing long jump from running start, the obstacle course, the grenade throw and the shot put were carried out in the earlier years (Tab. 4a). 
Table 4b. Types of motor tests applied in research on $1^{\text {st }}$ year students attending Polish tertiary institutions between 1970-1995

\begin{tabular}{|c|c|c|c|c|c|c|c|c|c|c|c|c|c|c|c|c|}
\hline \multirow[b]{2}{*}{ Types of motor tests } & \multicolumn{16}{|c|}{ Years of applying specific motor tests and numbers of individual authors' publications } \\
\hline & $\begin{array}{l}\frac{1}{\alpha} \\
\frac{1}{2} \\
\frac{1}{2}\end{array}$ & $\begin{array}{l}\frac{n}{a} \\
\frac{1}{2} \\
\frac{2}{2}\end{array}$ & $\begin{array}{l}\frac{2}{a} \\
\frac{1}{1} \\
\frac{1}{2}\end{array}$ & $\begin{array}{l}\frac{n}{5} \\
\frac{1}{2} \\
\frac{\hat{a}}{a}\end{array}$ & $\frac{n}{\frac{n}{2}}$ & 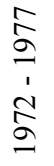 & $\stackrel{+}{\stackrel{\Delta}{ડ}}$ & $\stackrel{+}{\stackrel{5}{a}}$ & $\frac{n}{\frac{1}{5}}$ & $\begin{array}{l}\stackrel{8}{\Omega} \\
\stackrel{\infty}{2}\end{array}$ & $\frac{2}{2}$ & $\stackrel{0}{2}$ & $\stackrel{\circ}{\stackrel{2}{a}}$ & 今ิ & $\begin{array}{ll}E & a \\
E & \infty \\
5 & 0 \\
= & 0\end{array}$ & $\stackrel{9}{a}$ \\
\hline Long distance runs ${ }^{\text {a) }}$ & & & & & & 77 & & & & & & & 8 & & & \\
\hline \multicolumn{17}{|l|}{$300 \mathrm{~m}$ distance run } \\
\hline Short distance runs ${ }^{\text {b) }}$ & & & & & & 77 & & & & & & & 8 & & & \\
\hline Shuttle runs ${ }^{c)}$ & & & & & & 77 & & & & & & & 8 & & 12 & \\
\hline Zig- zag run & 23 & 46 & 5 & 4 & 42 & & 47 & 32 & 6 & 86 & 14 & 45 & & 44 & 12 & 57 \\
\hline \multicolumn{17}{|l|}{$\begin{array}{l}\text { Skipping with clapping of } \\
\text { hands }-8 \mathrm{~s}\end{array}$} \\
\hline \multicolumn{17}{|l|}{ Cooper test (12 min) } \\
\hline \multicolumn{17}{|l|}{ Marches d) } \\
\hline Standing long jump ${ }^{\mathrm{e})}$ & 23 & 46 & 5 & 4 & 42 & 77 & 47 & 32 & 6 & 86 & 14 & & 8 & & & 57 \\
\hline Vertical jump (Sargent's) & & & 5 & 4 & & & 47 & & 6 & & & 45 & & 44 & 12 & \\
\hline \multicolumn{17}{|l|}{ Grenade throw } \\
\hline \multicolumn{17}{|l|}{ Shot put ${ }^{\text {f) }}$} \\
\hline \multicolumn{17}{|l|}{ Obstacle course } \\
\hline Medicine ball throw ${ }^{\mathrm{g}}$ ) & 23 & 46 & & 4 & 42 & & 47 & 32 & 6 & 86 & 14 & & & 44 & 12 & 57 \\
\hline $\begin{array}{l}\text { Downward bend from } \\
\text { standing position }\end{array}$ & & & 5 & 4 & & 77 & & & 6 & & & & 8 & & & \\
\hline $\begin{array}{c}\text { Flexibility test } \\
\text { (Szafarkiewicz's) }\end{array}$ & & & & & & & 47 & & & & & & & & & \\
\hline \multicolumn{17}{|l|}{ Sit and Reach } \\
\hline $\begin{array}{l}\text { Squats with backward legs } \\
\text { extentions }{ }^{\text {h }}\end{array}$ & & & & & & & 47 & & & & & & & & 12 & \\
\hline Hand dynamometer trial & & & & & & & & & & & & & & & & 57 \\
\hline \multicolumn{17}{|l|}{ Balance trial (Flamini’s) } \\
\hline \multicolumn{17}{|l|}{ Tapping } \\
\hline Sit-ups-30s & & & & & & 77 & & & & & & & 8 & & & \\
\hline Flexed-arm hang & & & & & & & & & & & & & 8 & & & \\
\hline \multicolumn{17}{|l|}{ Push-ups } \\
\hline Pull-ups on a bar & & & & & & 77 & & & & & & & & & & \\
\hline \multicolumn{17}{|l|}{ Rowing ergometer- $500 \mathrm{~m}$} \\
\hline ETKF $\mathrm{VO}_{2 \max }$ & & & & & & & & & & & & & & & & \\
\hline
\end{tabular}

Note: a - most frequent 1000, i 500m; b-most frequent $100 \mathrm{~m}$, as well as $60 \mathrm{~m}$ or $50 \mathrm{~m}$; c - 4x10m or $4 \times 18 \mathrm{~m}$ or $4 \times 5 \mathrm{~m}$; $\mathrm{d}-10 \mathrm{~km}$ and $5 \mathrm{~km}$; e - originally mainly from a running start, later from a standstill; $\mathrm{f}-7,25 \mathrm{~kg}$ shot put (men) and $0,5 \mathrm{~kg}$ (women); g- backward or forward, $3 \mathrm{~kg}$ ball (men) and $2 \mathrm{~kg}$ ball(men and women); $\mathrm{h}$ - in duration 30s or 60s.

There was also a group of tests that were popular over the whole period of the research, among which there were: the zig-zag run, the standing long jump and the medicine ball throw (Tab. $4 \mathrm{a}-4 \mathrm{~b}$ ). The other tests were rather characteristic of the years in the middle and late stage of this period (Tab. $4 b$ \& $4 c$ ). Some studies on students' motor fitness were carried out cyclically, from time to time for a certain time. There were found 22 cases of cross-sectional tests applied more than once at a given school of higher education. Among those tests the vast majority was conducted in the earlier years of the period between 1954-2010. In contrast, single measurements were carried out predominantly in the 90's. 
Furthermore, it was observed that some of the studies were carried out on the basis of the tests batteries, among which the most popular was the Pilicz's test composed of three trials, such as: the standing long jump, the backward overhead medicine ball throw and the zig-zag run. Curiously, the InternationalTest of Physical Fitness (Pilicz, Przewęda, Dobosz, \& Nowacka -Dobosz, 2002) and the Eurofit (Szopa \& Grabowski, 1991) tests were applied only once.

Table $4 \mathrm{c}$. Types of motor tests applied in research on motor fitness of $1^{\text {st }}$ year students attending Polish tertiary institutions between 1993-2010

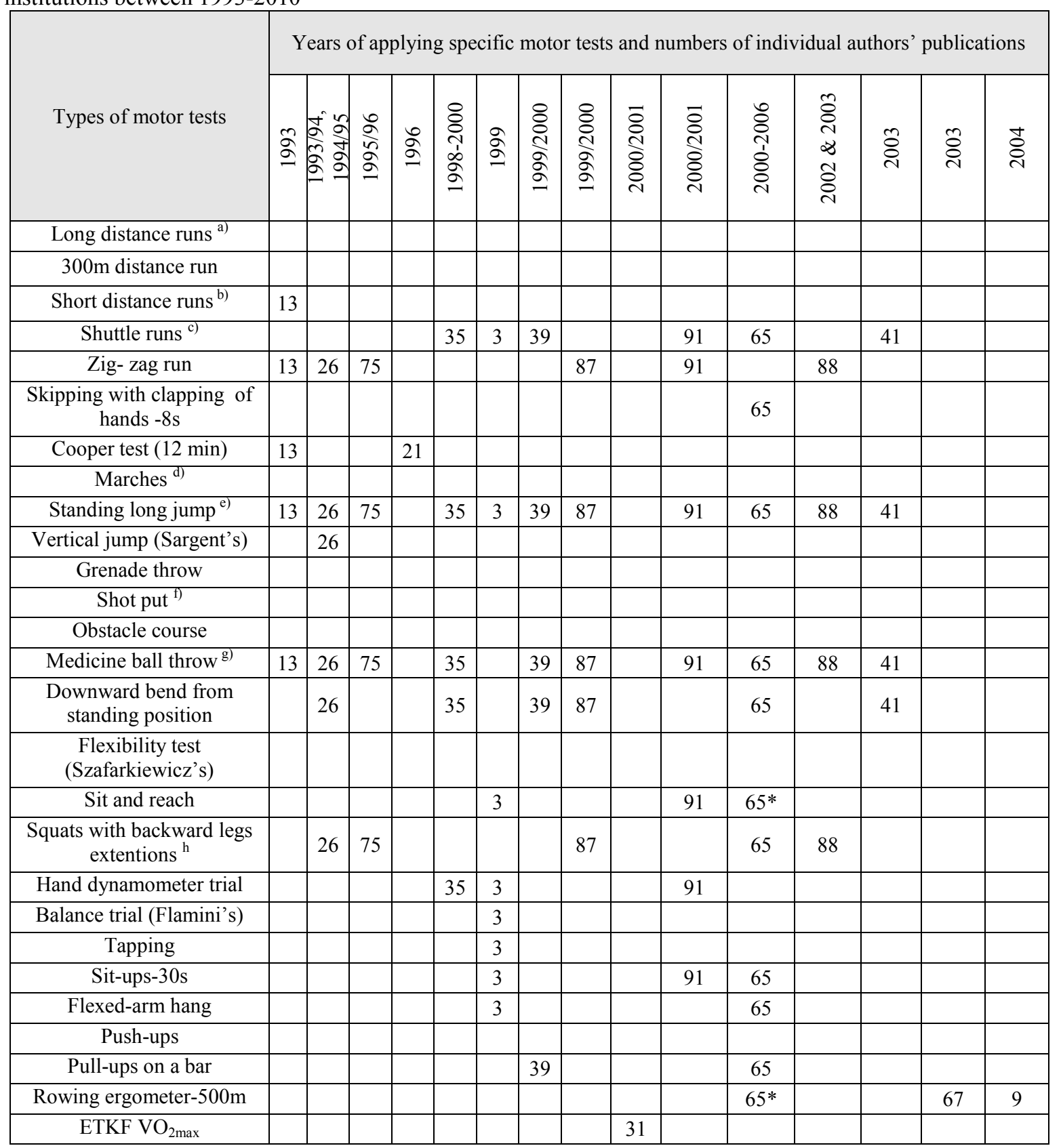

Note: a - most frequent 1000 , i $500 \mathrm{~m} ; \mathrm{b}$ - most frequent $100 \mathrm{~m}$, as well as $60 \mathrm{~m}$ or $50 \mathrm{~m} ; \mathrm{c}-4 \times 10 \mathrm{~m}$ or $4 \times 18 \mathrm{~m}$ or $4 \times 5 \mathrm{~m}$; d - $10 \mathrm{~km} \mathrm{i} 5 \mathrm{~km}$; e - originally mainly from a running start, later from a standstill ; f - 7,25kg shot put (men) and $0,5 \mathrm{~kg}$ (women); g- backward or forward, $3 \mathrm{~kg}$ ball (men) and $2 \mathrm{~kg}$ ball(men and women); $\mathrm{h}-$ in duration $30 \mathrm{~s}$ or $60 \mathrm{~s}$, ,*" trials added in 2006

\section{Discussion}

Clearly targeted review of the publications on the research concerning first-year-students' motor fitness at selected Polish schools of higher education provokes the following reflections. Despite a thorough analysis of the literature, it is impossible to fully interpret all the studies that involved first-year students due to a rather vague presentation of the results in the number of publications, some of which omitted to inform on the year of the conducted research, or the number of first-year students participating in the study, or even their gender. In other publications, while referring to specific motor trials, the author's name was provided with no indication of the type of the tests applied. It should be noted, however, that it is a common practice among the Polish scientists in this field that some motor tests are designed and then modified by the same author (Pilicz, 1997), which in consequence increases difficulty in analyzing and reviewing the works used in this research. 
Generally, the number of studies on the motor fitness of first-year students conducted between 1953-2010 is far from substantial and, arguably, insufficient to offer constant and regular monitoring of the Polish students' physical condition. This is the result of too large dispersions of the tests in time and the territory of Poland. The data obtained from the research related to particular academic centers focusing primarily on the inhabitants of a given region of the country.

In the motor tests conducted between 1953 - 2010, the trials varied in terms of nomenclature and were applied to evaluate diverse motor abilities. For example: the zig-zag run was used for measuring movement coordination, speed, and agility, whereas the standing long jump assessed jumping ability, explosive strength or the power of the lap belt. On the other hand, the $300 \mathrm{~m}$ race was a measure of endurance. In view of the currently accessible literature, it could be tempting to speculate as to why there is such a differentiated approach, which could conceivably stem from the researcher's contrasting views on the concept of human motor fitness.

A closer observation of the collected data leads to another conclusion: in the majority of the reported studies the authors tend to present the tests without classifying which of the applied motor trials assess the level of a given motor ability. A deeper analysis, based on the increased number of differentiation factors (golden standards), would have certainly resulted in the research findings broader in scope and pregnant with numerous practical applications. Such an omission may be due to the fact that the main studies on the structure of human motor fitness that have led to significant progress in the identification, naming and conceptual hierarchy, accuracy and validity of many of these trials were conducted in the 80's and 90's of the $20^{\text {th }}$ century in Poland (mainly in the Polish centers of Cracow and Katowice) (Raczek, 1989, 1990, 1993; Szopa, 1989, 1998; Szopa, Mleczko, \& Żak, 1996, Szopa, Chwała, \& Ruchlewicz, 1998).

The group of the most commonly used tests included the trails such as: the standing long jump, the medicine ball throw and the zig-zag run. Out of the above tests, some of them are marked by a high rate of accuracy and validity relevant for the indirect motor tests used for measuring specific motor abilities. Assuming the validity of the classification by Szopa, Chwała, \& Ruchlewicz (1998) it is clear that the indirect motor test such as the medicine ball backward throw is the most accurate in assessing the ability to develop the absolute maximum static strength (in the group of strength abilities), whereas the standing long jump precisely determines the ability to develop maximum anaerobic nonlactic acid power(in the group of speed abilities). In turn, the selected shuttle runs andzig-zag runs are associated with the ability to rapidly mobilize the muscle (in the group of speed abilities).

In an attempt to analyze the battery of tests designed to measure so-called 'general motor fitness', the downward bend from standing position is frequently used in the studies of this type due to its ease and affordability. It should be noted that in the opinion of some authors there are big concerns as to its accuracy and validity in measuring flexibility (Podstawski, 2008; Żak \& Sakowicz, 1996). Furthermore, the use of only one test while assessing specific motor abilities raises serious doubts as for the overall assessment of the motor level of a particular motor ability. Relying on one measurement (motor trial) only leaves no ground for any attempts to determine so- called' overall level of motor abilities', but only its manifestation, which in the case of the downward bend from standing position trial may refer to the flexibility of spine in the sagittal plane and mainly in the lumbar region. Accurate logic reasoning in this regard is confirmed inter alia in the study by Szopa, who stated that ,physical fitness should be mainly classified on the basis of three elements: the time - space structure of movement, its intensity and load" (Szopa, 1998, p. 84], which was supplemented by Mynarski (2000, p. 152) with "age and sex of the subjects in terms of the importance of individual abilities in the whole of their motor potential (capacity)".

Consequently, a defined motor test will not always assess accurately and reliably the level of motor abilities in individuals differentiated by sex and their developmental stage. The classification of particular motor abilities can be viewed only in terms of the dominant, which is reflected in a given motor task (Raczek, 2010, p. 25), since the vast majority of the movements performed by man does not measure specific abilities but their combinations (in the dynamic system with predispositions).

Of all the research presented in the study the most valuable are the measurements carried out simultaneously in many academic centers involving large populations of the students (Demel \& Sikora, 1959; Pilicz, 1963, 1982). Those studies were quite pioneering as they incorporated fitness tests often utilitarian in nature (as efficiency in work), referring to athletic and defense disciplines. The illustration of this can be: the $100 \mathrm{~m}, 500 \mathrm{~m}$, and $1000 \mathrm{~m}$ races, the standing long jump from running start, the obstacle course, the grenade throw and the shot put trial. Interestingly, an attempt to complete Kuraś's obstacle course (Kuraś, 1969) was for a long time in the 1990s part of the entrance exams to the Academy of Physical Education in Cracow.

Some of the works were devoted to evaluating the relationships between morphological parameters and motor performance (Podstawski, Choszcz, \& Wysocka-Welanc, 2006; Choszcz, Podstawski, \& Wysocka-Welanc, 2009), whereas the others were based on specially designed for this purpose so-called general motor fitness tests, such as: the "EUROFIT", and the "International Test of Physical Fitness" developed by the International Committee on the Standardization of Physical Fitness Tests (Pilicz, Przewęda, Dobosz, \& Nowacka-Dobosz, 2002). The vast majority of the works which related to the subject of first-year students' motor fitness was based on one-off measurements, in contrast to longitudinal studies which occurred occasionally and were systematically repeated (Grus, 1977, 1980; Jaskólski, Niemiec, \& Śliwa, 1972; Pilicz, 1963; Podstawski, 2010; Szymański, 1998).

The main objectives and importance of motor fitness measurements have been widely described in the Polish literature of this field (Drabik, 1997, 2006; Mynarski, Garbaciak, Stokłosa, \& Grządziel, 2007;Osiński, 2003; Pilicz, 1996, 1997; Przewęda \& Dobosz, 2007; Raczek, 2010; Szopa \& Grabowski, 1991). Conducting this type of research is undoubtedly of practical value to university authorities as they are provided with the basic information on the health status of students entering university, which if necessary they can affect by promoting health conscious attitudes. This 
can be achieved by implementing effective and attractive physical education programs which would make use of the results of motor tests conducted with the students so as to increase their motivation to participate in various forms of physical activity. Graduates of higher education, due to the future social status, can and should have an influence on the public in strengthening health-conscious attitudes (Podstawski, 2006). Also, it is graduates of higher education who will largely determine the scale of progress in shaping pro-health attitudes with its essential attribute - physical activity (Lisicki, 2006). Numerous studies in developed countries have revealed that increasing affluence of societies does not result in better health (Guajardo, Warren, \& Wang, 2013). On the contrary, public health is even deteriorating and yet to be improved (Blair, 2009; Obama, 2012). The recovery of this negative phenomenon should take place in the course of the studies by specially designed remedial measures that should be also taken within the academic P.E. classes prepared and conducted by competent staff (Podstawski \& Sławek, 2012). Properly organized P.E. classes as well as additional elective courses should bear fruit in maintaining proper physical condition resulting from an adequate level of physical activity and by this motor fitness, as a specific outcome of health (Lee, Burgeson, Fulton, \& Spain, 2007). The level of physical activity of Polish society is still one of the lowest in Europe (Starosta, 2010). In this context undertaking a study the aim of which is to determine the level of motor fitness of students seems to be advisable and necessary. In the opinion of the present author the evaluation of physical activity by means of relevant measurements of the level of motor fitness is by far the most accurate method of assessment in this regard.

\section{Conclusions}

A thorough analysis of the Polish literature concerning motor fitness leads to the following conclusions:

1. It was established that there is a small number of works (45 publications) devoted to the study on the level of motor fitness of the first-year students attending Polish tertiary institutions in the years 1953-2010. Out of all the conducted and published research, 19-related to both sexes, 15 - refers to women only and 11 only to men;

2. The highest number of conducted and recorded research were done in technical schools of higher education (21 cases), followed by universities (12 cases), and medical academies (10 cases). A considerably smaller number of research on motor fitness was found in other types of institutions of higher education in Poland including the smallest number in economic colleges ( 2 cases);

3. The groups which covered the largest number of students in the first year of their study were conducted by: Demel and Sikora in 1954 (11907 women and men), Pilicz in 1979 (7180 women and men) and Pilicz in the years 1954-1959 (6395 men);

4. In all the studies 27 motor tests were performed, several of which such as: short distances races, shuttle runs, marches, shot puts, medicine ball throws, and squats with backward legs extensions (Burpee tests) had different variations. The occurrence of cross-sectional studies concerning secular trends in the level of motor fitness or specific motor abilities was occasional. The most commonly used tests included the trials such as: the standing long jump ( 37 cases), the medicine ball throw (28 cases) and the zig-zag run (27 cases);

5. Taking into account the years of the study it was found that the trials such as: short distance races, marches, the standing long jump from running, the obstacle course, the grenade throw and shot put trials were characteristics of the earlier years, whereas the tests such as: the zig-zag run, the standing long jump, the medicine ball throw were popular throughout the period under study. New motor tests were applied alongside the previously used and the position and the popularity of some was strengthened.

\section{References}

Astrand, P. O. (2000). Dlaczego wysiłek? Medicina Sportiva, 4(2), 83-100.

Blair, S. N. (2009). Physical Inactivity: The biggest Public Health Problem of the 21st Century. British Journal of Sports Medicine, 43, 1-2.

Bratkowska-Gołaszewska, E. (2000). Budowa somatyczna i sprawność motoryczna studentek i studentów I roku Akademii Rolniczo-Technicznej w Bydgoszczy - stan badań, in Dziubiński, Z., \& Gorski, B. (eds.), Kultura fizyczna studentów $w$ okresie transformacji szkolnictwa wyższego w Polsce (pp. 109-113). Warszawa: Politechnika Warszawska Press.

Brodecki, Z. (1977). Rozwój fizyczny i sprawność fizyczna ogólna studentek i studentów I roku Wyższej Szkoły Inżynierskiej w Zielonej Górze w latach 1972-1975, in Wartość biologiczna młodzieży akademickiej Polski (pp. 151157). Seria: Monografie Nr 91. Poznań: AWF Press.

Burdziński, Z. (1977). Rozwój fizyczny i sprawność motoryczna studentek I roku Uniwersytetu im. Adama Mickiewicza w Poznaniu w świetle 4-letnich badań, in Wartość Biologiczna Młodzieży Akademickiej Polski (pp. 125130). Seria: Monografie Nr 91. Poznań: AWF Press.

Burdziński, Z. (1977). Z badań związków rozwoju fizycznego i sprawności fizycznej studentów Uniwersytetu im. Adama Mickiewicza w Poznaniu, in Rozwój fizyczny i sprawność fizyczna młodzieży akademickiej Poznania (pp. 21 25). Seria: Monografie Nr 98. Poznań: AWF Press.

Caspersen, C. J., Powell, K. E, \& Christenson, G. M. (1985). Physical Activity, Exercise, and Physical Fitness: Definitions and distinctions for Health-Related Research. Public Health Reports, 100(2), 126-131.

Chlebicka, E. (1983). Sprawność fizyczna studentek Uczelni Technicznej w zależności od pochodzenia środowiskowego. Prace Studiów Wychowania Fizycznego i Sportu Uczelni Technicznych, 9, 21-31.

Choszcz, D., Podstawski, R., \& Wysocka-Welanc, M. (2009). Measurement of motor fitness of students using the rowing ergometer. Human Movement, 10(1), 46-52.

Corbin, C. B. (2002). Physical activity for everyone; what every physical educator should know about promoting lifelong physical activity. Journal of Teaching in Physical Education, 21, 128-144. 
Crespo, C. J., Ainsworth, B. E., Keteyian, S. J., Health, G. W., \& Smit, E. (1999). Prevalence of physical inactivity and its relation to social class in U.S. adults: results from the third national health and nutrition examination survey, 1988-1994. Medicine and Science in Sport and Exercise, 31, 1821-1827.

Czapla, K., \& Malanowicz, J. (1979). Próba oceny sprawności i budowy somatycznej studentów Politechniki Śląskiej i Technische Hochschule Magdeburg, in Obodyński, K. (eds.), Kultura Fizyczna w Szkołach Wyższych (pp. 59-65). Rzeszów: WSP Press.

Czaplicki, Z. (1997). Sprawność fizyczna młodzieży akademickiej WSP w Olsztynie. Wychowanie Fizyczne $i$ Zdrowotne, 2, 90-91.

Deckert, A., \& Kobielski, B. (1977). Charakterystyka somatyczna oraz sprawność fizyczna studentów Akademii Medycznej w Poznaniu w roku akademickim 1976/77, in Rozwój fizyczny i sprawność fizyczna młodzieży akademickiej Poznania (pp. 85-89). Seria: Monografie nr 98. Poznań: AWF.

Demel, M, \& Pilicz, S. (1966). Rozwój i sprawność fizyczna młodzieży akademickiej. Przekroje porównawcze 19541964. Kultura Fizyczna, 8-9, 261-264.

Demel, M., \& Sikora, W. (1959). Badania nad rozwojem fizycznym i sprawnością ruchową młodzieży akademickiej. Wychowanie fizyczne i Sport, 3(4). 555-557.

Dishman, R. K., Sallis, J. F., \& Orenstein, D. R. (1985). The determinants of physical activity and exercise. Public Health Reports, 100, 158-171.

Drabik, J. (1989). Wytrzymałość i jej uwarunkowania somatyczne u dzieci i młodzieży w wieku 8-19 lat. Gdańsk: AWFiS Press.

Drabik, J. (1997). Aktywność, sprawność i wydajność fizyczna jako mierniki zdrowia człowieka. Gdańsk: AWF Press. Drabik, J. (2006). Pedagogiczna kontrola pozytywnych mierników zdrowia fizycznego. Gdańsk: AWFiS Press.

Drabik, J., \& Orzechowski, K. (1999). Sprawność krążeniowo-oddechowa studentów medycyny w świetle testu Coopera. Medicina Sportiva, 3(4), 273-278.

Erikssen, G. (2001). Physical fitness and changes in mortality: the survival of the fittest. Sports Medicine, 31(8), 571576.

Grus, J. (1977). Rozwój fizyczny oraz sprawność fizyczna studentów Państwowej Wyższej Szkoły Sztuk Plastycznych w Poznaniu w latach 1970/71 do 1974/75, in Wartość biologiczna młodzieży akademickiej Polski (pp. 131-136). Seria: monografie Nr 91, Poznań, AWF,.

Grus, J. (1977). Z badań rozwoju fizycznego i sprawności fizycznej młodzieży przyjętej na studia muzyczne w Poznaniu w latach od 1965 do 1974, w: Wartość biologiczna młodzieży akademickiej Polski(pp. 137-142). Seria: Monografie Nr 91. Poznań: AWF Press.

Grus, J. (1980). Charakterystyka porównawcza rozwoju fizycznego i sprawności fizycznej studentów wyższych szkół artystycznych Poznania z lat 1955-59, $1965-69$ oraz 1975-76, in Rozwój fizyczny $i$ sprawność fizyczna dzieci $i$ młodzieży Ziem Północno-Zachodnich Polski (pp. 155-159). Poznań, AWF Press, Seria: Monografie Nr 149.

Grzesiak, J. (1998). Charakterystyka sprawności fizycznej studentów z Zielonej Góry, in Chromiński, Z. (eds.), Integracja systemowa wychowania ekologicznego fizycznego i zdrowotnego (pp. 131-138). Człuchów: UM Press.

Guajardo, F., Warren, B., \& Wang, L. (2013). Self-Organizing: From Child's Play to An Effective Wellness Program. International Journal of Kinesiology \& Sports Science, 1(1), 16-25.

Howley, E. T., \& Franks, B. D. (1997). Health Fitness Instructor's handbook. Human Kinetics Publishers.

Jaskólski, E., Niemiec, S., \& Śliwa, W. (1970). Zależność poziomu rozwoju fizycznego studentów Politechniki Wrocławskiej od wieku w przedziale 18-22 lat. Wychowanie Fizyczne i Sport, 3, 73-80.

Jaskólski, E., Niemiec, S., \& Śliwa, W. (1972). Wpływ programowych zajęć wychowania fizycznego podczas I roku studiów, na sprawność fizyczną młodzieży Politechniki Wrocławskiej. Zeszyty Naukowe Wyższej Szkoły Wychowania Fizycznego we Wrocławiu. 11, 73-81.

Jopkiewicz, A, Przychodni, A., \& Markowska, M. (2004). Cechy budowy morfologicznej a wydolność fizyczna studentów, in Jopkiewicz, A. (eds.), Auksologia a promocja zdrowia (pp. 61-71). Kielce.

Jopkiewicz, A., \& Kosztołowicz, M. (1978). Próba ustalenia norm sprawności fizycznej studentek i studentów na podstawie badań eksperymentalnych. Wychowanie Fizyczne i Sport, 2, 113-123.

Kemper, H. C. G. (1995). The Amsterdam growth study. A longitudinal analysis of health, fitness, and lifestyle. Human Kinetics, Champaign.

Kobielski, B., \& Konior, W. (1958). Rozwój fizyczny i sprawność młodzieży akademickiej I roku Akademii Medycznej w Poznaniu. Kultura Fizyczna, 11, 778-789.

Kuchnio, M., \& Forjasz, J. (2006). Wybrane próby sprawności motorycznej a cechy somatyczne młodzieży (19-21 lat) o różnym poziomie aktywności ruchowej. Aktywność ruchowa ludzi w różnym wieku, 10, 266-272.

Kuraś, Z. (1969). Metoda syntetycznej oceny ogólnej sprawności fizycznej. Roczniki Naukowe AWF w Warszawie, $10,94$.

Labbe, A. E., \& Welsh, C. (1993). Children and running: Changes in Physical Fitness, Self-Efficacy, and Health Locus of Control. Journal of Sport Behavior, 16 (2), 85-91.

Lee, S. M., Burgeson, Ch. R., Fulton, J. E., \& Spain, Ch. G. (2007). Physical Education and Physical Activity Results From the School Health Policies and Programs Study 2006. Journal of School Health, 77(8), 435-463.

Lisicki, T. (2002). Ogólna sprawność fizyczna oraz postawy wobec profilaktyki zdrowotnej $i$ aktywności ruchowej studentów I roku studiów. Na przykładzie studentów szkół wyższych Trójmiasta. Gdańsk: AWFiS Press.

Lisicki, T. (2006). First year students of medical universities compared with health lifestyle requirements. Gdańsk, AWFiS Press. 
Lisicki, T., \& Drygas, A. (2005). Sprawność fizyczna studentek Collegium Medium w Bydgoszczy, in Lisicki, T., Wilk, B., \& Walentukiewicz, A. (eds.), Prozdrowotny styl życia. Uwarunkowania społeczne (pp. 407-414). Gdańsk: AWFiS Press.

Malanowicz, J. (1977). Rozwój fizyczny i sprawność fizyczna studentów przyjętych na Politechnikę Śląską w latach 1972-1975. Prace Naukowe Instytutu Organizacji i Zarzadzania Politechniki Wrocławskiej, 17, 113-119.

Marsh, H. W. (1993). The multidimensional structure of physical fitness: invariance over gender and age. Research Quarterly for Exercise and Sport, 64(3): 265-273.

Mroczkowska, K. (1979). Próba oceny sprawności fizycznej studentek Wyższej Szkoły Morskiej w Gdyni w roku akademickim 1977/78. Prace Studiów Wychowania Fizycznego i Sportu Uczelni Technicznych, 6, 133-137.

Mroczkowski, R. (1976). Sprawność fizyczna studentów I roku Wyższej Szkoły Morskiej w Gdyni w roku akademickim 1975 - 1976, in Wartość Biologiczna Młodzieży Akademickiej Polski (pp. 269-272). Seria: Monografie Nr 91. Poznań: AWF Press.

Mroczyński, B. (1974). Sprawność fizyczna ogólna studentek ATR w Bydgoszczy w latach 1970-1973. Prace Studiów Wychowania Fizycznego i Sportu Uczelni Technicznych, 2, 176-178.

Mroczyński, B. (1979). Próba oceny rozwoju i sprawności fizycznej studentów akademii Techniczno-Rolniczej w Bydgoszczy w okresie dwóch lat studiów. Prace Studiów Wychowania Fizycznego i Sportu Uczelni Technicznych, 6 , 183-186.

Mynarski, W. (2000). Struktura wewnętrzna zdolności motorycznych dzieci i młodzieży w wieku 8-18 lat, in Raczek, J. (eds), Studia nad motorycznościa ludzka (pp. 9-34), Katowice: AWF Press.

Mynarski, W., Garbaciak, W., Stokłosa, H., \& Grządziel, G. (2007). Sprawność fizyczna ukierunkowana na zdrowie (H-RF) Populacji Górnego Śląska. Katowice: AWF Press.

Obama, M. (2012). The First Lady speaks out. Vibrant Life Sep/Oct2012, 28(5), 32-33.

Osiński, W. (1998). Tendencies of Construction of the Physical Fitness in the Conception of „Health-Realted Fitness”. Antropomotoryka, 17, 175-193.

Osiński, W. (2003). Antropomotoryka. Poznań: AWF Press.

Pangrazi, R. P., Corbin, C. B., \& Welk, G. J. (1996). Physical activity for children and youth. Journal of Physical Education, Recreation and Dance, 67(4), 38-46.

Pilicz, S. (1958). Sprawność młodzieży męskiej I roku Politechniki Warszawskiej w roku akademickim 1953/54. Kultura Fizyczna, 3, 7-14.

Pilicz, S. (1963). Rozwój i sprawność fizyczna studentów Politechniki Warszawskiej. Wychowanie Fizyczne i Sport, $7(1), 106-122$.

Pilicz, S. (1973). Sprawność fizyczna studentów Politechniki Warszawskiej w roku 1954-1969. Kultura Fizyczna, 10, 453-454.

Pilicz, S. (1982). Sprawność fizyczna studentów rozpoczynających studia w Polsce. Zeszyty Naukowe AWF Wrocław, 28, 333-338.

Pilicz, S. (1996). Pomiar sprawności fizycznej w wychowaniu fizycznym. Wychowanie Fizyczne i Zdrowotne, 2, 2258.

Pilicz, S. (1997). Pomiar ogólnej sprawności fizycznej. Warszawa: AWF Press.

Pilicz, S., Przewęda, R., Dobosz, J., \& Nowacka-Dobosz, S. (2002). Physical Fitness Score Tables of Polish Youth. Criteria for Measuring Aerobic Capacity by the Cooper Test. Warszawa, AWF Press.

Pilicz, Z. (1971). Rozwój i sprawność fizyczna studentek Politechniki Warszawskiej w latach 1966-1968. Akademicki Sport i Wychowanie Fizyczne, 9, 60-62.

Pilicz, Z. (1973). Pochodzenie społeczne a sprawność fizyczna studentek Politechniki Warszawskiej w roku 1965 i 1969. Klutura Fizyczna, 10, 455-458.

Podstawski, R. (2006). Physical ability and opinions on health prevention among the 1st year students of the University of Warmia and Mazury in Olsztyn in academic year 1999/2000. Olsztyn, UWM Press.

Podstawski, R. (2008). Sprawność fizyczna studentów I roku studiów Uniwersytetu Warmińsko-Mazurskiego w Olsztynie w roku akademickim 2003/2004 w odniesieniu do roku 2001/2002. Aktywność ruchowa ludzi w różnym wieku, 12, 216-223

Podstawski, R. (2010). Characteristics of changes in speed abilities of the first year female students of Warmia and Mazury University in Olsztyn (2000-2006). Aktywność ruchowaludzi w różnym wieku, 14, 159-170.

Podstawski, R., \& Sławek, M. (2012). The Influence of Political Transformation in Poland on the Functioning on the Department of Physical Education and Sport at the University of Warmia \& Mazury in Olsztyn During the Academic Years of 1998/2011 and 2010/2011., in Sokołowska, B. (eds.), Public Health in the Aspect of Modern Civilization (pp. 266-278). Biała Podlaska: PSWJP II Press.

Podstawski, R., Choszcz, D., \& Wysocka-Welanc, M. (2006). Określenie wpływu wysokości i masy ciała kobiet na czas pokonania dystansu $500 \mathrm{~m}$ na ergometrze wioślarskim. Antropomotoryka, 34, 69-76.

Przewęda, R., \& Dobosz, J. (2007). Kondycja fizyczna polskiej młodzieży. Studia i Monografie. Warszawa: AWF Press.

Przewęda, R., \& Trześniowski, R. (1996). Sprawność fizyczna polskiej młodzieży w świetle badań z roku 1989. Studia i Monografie.Warszawa, AWF Press.

Raczek, J. (1989). Teoria motoryczności (antropomotoryka) w systemie nauk o kulturze fizycznej. Antropomotoryka, $1,5-18$.

Raczek, J. (1990). Czy rzeczywiście nowa i zasadna koncepcja klasyfikacji i struktury motoryczności człowieka. Antropomotoryka, 4, 71-84. 
Raczek, J. (1991). Teoretyczna koncepcja motoryczności człowieka - próba strukturalizacji i klasyfikacji, in Raczek, J. (eds.), Podstawowe problemy badawcze w naukach o kulturze fizycznej (26-36). Katowice: AWF Press.

Raczek, J. (1993). Koncepcja strukturalizacji i klasyfikacji motoryczności człowieka, in Osiński, W. (eds.), Motoryczność człowieka - jej struktura, zmienność i uwarunkowania (pp. 63-80). Monografie, Podręczniki Skrypty, No. 310. Poznań: AWF Press.

Raczek, J. (2010). Antropomotoryka. Teoria motoryczności człowieka w zarysie. Warszawa: PZWL.

Rodziewicz-Gruhn, J., Pyzik, M., Rak, L., Baczyński, W., \& Zuch, H. (1997). Zróżnicowanie sprawności motorycznej studentek I roku z Wyższej Szkoły Pedagogicznej w Częstochowie studiujących na różnych kierunkach, in Prace Naukowe Wyższej Szkoły Pedagogicznej w Częstochowie (pp. 139-145). Seria: Kultura fizyczna, z. I. Częstochowa: WSP Press.

Silski, A. (1966). Sprawność i rozwój fizyczny studentów Politechniki Poznańskiej w zależności od uprawiania sportu. Roczniki Naukowe WSWF w Poznaniu, 12, 145-149.

Silski, A. (1981). Sprawność ruchowa studentów I roku Politechniki Poznańskiej w latach 1972 - 1977. Prace Studiów Wychowania Fizycznego i Sportu, 7, 142-145.

Skinner, S. J., Oja, P. (1994). Laboratory and field tests for assessing health-realated fitness, in Bouchard, C., Shephard, R. J., \& Stephens, T. (eds.), Physical activity, fitness, and health (160-179). Champaign, I11., Human Kinetics Publishers.

Starosta W. (2010). How one should understand the biological minimum of daily movement activity and how important it is for the human health? Aktywność ruchowa ludzi w różnym wieku, 14, 49-65.

Szopa, J. (1989). Nowa koncepcja klasyfikacji i struktury motoryczności człowieka. Antropomotoryka, 2, 3-8.

Szopa, J. (1998). Structure of Motor abilities - Identification and Measurements. Antropomotoryka, 18, 79-86.

Szopa, J. (1999). Wpływ zwiększonej aktywności ruchowej na poziom rozwoju somatycznego i funkcjonalnego: problemy metodologiczne i stan badań, in Kłyszejko, J. (eds.), Aktywność fizyczna. Drugie warsztaty antropologiczne (pp. 49-69). Warszawa, AWF Press.

Szopa, J., \& Grabowski, H. (1991). EUROFIT. Europejski Test Sprawności Fizycznej. Kraków, AWF Press.

Szopa, J., Chwała W., \& Ruchlewicz, T. (1998). Investigations on Structure of „Energetic” Motor Abilities in Children and Youth. Antropomotoryka, 17, 3-41.

Szopa, J., Mleczko, E., \& Żak, S. (1996). Podstawy antropomotoryki. Warszawa-Kraków: PWN.

Szymański, T. (1998). Poziom rozwoju fizycznego i sprawności motorycznej studentek rozpoczynających studia na WSP w Bydgoszczy w latach 1975-1995, in Wachowski, E, \& Pietrusik, K. (eds.), Wychowanie fizyczne i sport w badaniach naukowych (pp. 81-95). Poznań: AWF.

Tatarczuk, J., \& Asienkiewicz, R. Sprawność motoryczna i wydolność fizjologiczna studentek Uniwersytetu Zielonogórskiego w ujęciu rytmu menstruacyjnego. Aktywność ruchowa ludzi w różnym wieku, 12, 374-380.

Tatarczuk, J., \& Wandycz, A. (2006). Wskaźnik tempa rozwoju i tendencje przemian w zakresie wybranych zdolności motorycznych studentów. Aktywność ruchowa ludzi w różnym wieku, 10, 319-323.

Tomkinson, G. R. (2007). Global changes in anaerobic fitness test performance of children and adolescents (19582003).Scandinavian Journal of Medicine \& Science in Sports, 17, 495-507.

Tomkinson, G. R., \& Olds, T.S. (2007). Secular changes in pediatric aerobic fitness tests performance: the global picture. Medicine and Sport Science, 50, 46-66.

Umiastowska, D. (2007). Zmiany modelu akademickiego wychowania fizycznego w świetle badań uczestnictwa szczecińskich studentów $w$ kulturze fizycznej. Rozprawy i Studia T. (DCCXLVIII) 674. Szczecin: Uniwersytet Szczeciński Press.

Wierzbicki, A. (1975). Aktywność ruchowa a zwinność studentów Akademii Rolniczej w Poznaniu; w Rozwój fizyczny i sprawność fizyczna młodzieży akademickiej Poznania. Seria: Monografie Nr 82. Poznań: AWF, 1975: 75-78.

Żak, S., \& Sakowicz, B. (1996). Gibkość - uwarunkowania strukturalne, testowanie i zmienność ontogenetyczna (próba oceny relatywnej). Antropomotoryka, 14, 67-82. 